\title{
13. CHERTS FROM RIO GRANDE RISE SEDIMENTS, DEEP SEA DRILLING PROJECT LEG 72, HOLE 516F 1
}

\author{
M. A. Levitan, V. P. Strizhov, and A. Ya. Schevtchenko, Institute of Oceanology, The Academy of Sciences of the \\ U.S.S.R., Moscow, U.S.S.R.
}

\begin{abstract}
Cherts recovered during DSDP Leg 72 from Rio Grande Rise sediments (Site 516) consist of both cristobalite and quartz, and contain ghosts of foraminifers and (more rare) radiolarians. Porcelanite made of disordered cristobalite is found in most old enclosing sediments. Local dissolution of siliceous microfossils during diagenesis is the most likely source of the silica required for the chert formation. As sediment age increases, the proportion of biogenic silica decreases and authigenic silica increases.
\end{abstract}

\section{INTRODUCTION}

Cherts are important as diagenesis stage indicators. One can connect the occurrence of chert with the history of paleocirculation, the evolution of silica accumulation, and other areas of study. Our study adds some detailed knowledge of the mineralogy, chemistry, and structure of cherts that may prove helpful in research dealing with these areas.

\section{METHOD AND DATA BASE}

We used optical and electron microscopy, X-ray diffraction, infrared absorption, and chemical analysis to investigate five samples from Hole 516F. Four of these (Samples 516F-4-6, 128-131 cm; $516 \mathrm{~F}$ $17-1,68-69 \mathrm{~cm} ; 516 \mathrm{~F}-17, \mathrm{CC}$; and $516 \mathrm{~F}-18-1,102-104 \mathrm{~cm})$ are quartzcristobalitic cherts; one (Sample $516 \mathrm{~F}-80-1,90-91 \mathrm{~cm}$ ) is a weakly carbonaceous cristobalitic porcellanite. The age of host sediments ranges from Eocene to Miocene. The following peaks were used for mineral identification on X-ray diffractograms: calcite, $3.03 \AA$; quartz, 3.33 $\AA$; opal-CT ( $\alpha$-cristobalite, 4.08 to $4.11 \AA \AA$ plus $\alpha$-trydimite, 4.27 to $4.29 \AA$ ); opal-A, halo in area $6-16^{\circ} 2 \theta$; dolomite, $2.903 \AA$. Biogenic opal-A has a halo in the area of $16-18^{\circ} 2 \theta$ (Calvert, 1971); so, in some cases, we can distinguish between biogenic and nonbiogenic opal-A on diffractograms.

The following characteristic bands can be used for the identification of different minerals from infrared spectra: calcite, 1440,880 , and $720 \mathrm{~cm}^{-1}$; opal-CT, 795 to $800 \mathrm{~cm}^{-1}$ with weak complication by quartz near $820 \mathrm{~cm}^{-1}$. All spectra show a well-marked band at 1640 $\mathrm{cm}^{-1}$ caused by the oscillation of molecular water. The $950 \mathrm{~cm}^{-1}$ band is connected with $\mathrm{Si}-\mathrm{OH}$ group.

\section{VISUAL CHARACTERISTICS}

The cherts are greenish gray, yellowish gray, and gray; they are weakly spotted with areas of more-or-less dark color and are very hard (no knife penetration). They have sharp boundaries and conchoidal fracture and do not react with $\mathrm{HCl}$. They form nests and lenses from 1-2 $\mathrm{mm}$ to as much as $60 \mathrm{~mm}$ in length (Fig. 1). They are enclosed in biomicrite nannoplankton-foraminiferal chalks and chalky limestones. A transition zone of white carbonate-siliceous rock 1-2 $\mathrm{mm}$ in width separates the

\footnotetext{
${ }^{1}$ Barker, P. F., Carlson, R. L., Johnson, D. A., et al., Init. Repts. DSDP, 72: Washing ton (U.S. Govt. Printing Office).
}

relatively big chert lenses from the carbonate. Boundaries between cherts and carbonate-siliceous rock are sharp and between the latter and carbonates either sharp or diffuse.

Porcellanite is distinctly different from chert. It resembles white, hard, carbonate-siliceous rock; however, it allows almost no knife penetration, does not show smooth fracture, and reacts weakly with $\mathrm{HCl}$.

One can readily see under the microscope that cherts have been formed by silicification of carbonates. A pelitomorphic matrix consisting of nannoplankton remains and, chiefly, authigenic calcite (micrite) has undergone partial replacement by opal. In some cases, the walls of foraminifers are replaced by microquartz. The chambers of foraminifers are filled with fibrous chalcedony, opal-CT, or authigenic calcite in various degrees, but empty chambers also occur. Opal-A of single spicules has undergone the conversion to opal-CT ( $\alpha$-cristobalite?). Very rare radiolarian skeletons have been calcitized in the cherts and in the transitional zone. This feature is very significant. Sometimes authigenic forms of $\mathrm{SiO}_{2}$, such as opal-CT, chalcedony, or micromozaic quartz, form short veins or elongated small lenses in intergranular spaces. Weak mechanical distension of host rocks may take place under these conditions. The weakly spotted structure of cherts (see macroscopic examination) is due to the conglomerate-like pattern of distribution of the rock areas (1-2 to $\left.25-30 \mathrm{~mm}^{2}\right)$; each has different ratios of $\mathrm{CaCO}_{3}$ and $\mathrm{SiO}_{2}$.

In thin section, the porcellanite differs from the above-described cherts by the absence of any forms of chalcedony or quartz, by generally weaker silicification, and by the presence of dolomite. Dolomite and opal-CT are found both in the matrix and in foraminiferal chambers.

These features of chemical and mineral composition of the siliceous rocks are corroborated and complemented by data of other analyses.

\section{CHEMICAL ANALYSES}

According to results of chemical analyses (Table 1), the samples from Hole $516 \mathrm{~F}$ consist of $\mathrm{SiO}_{2}(60-76 \%)$, 

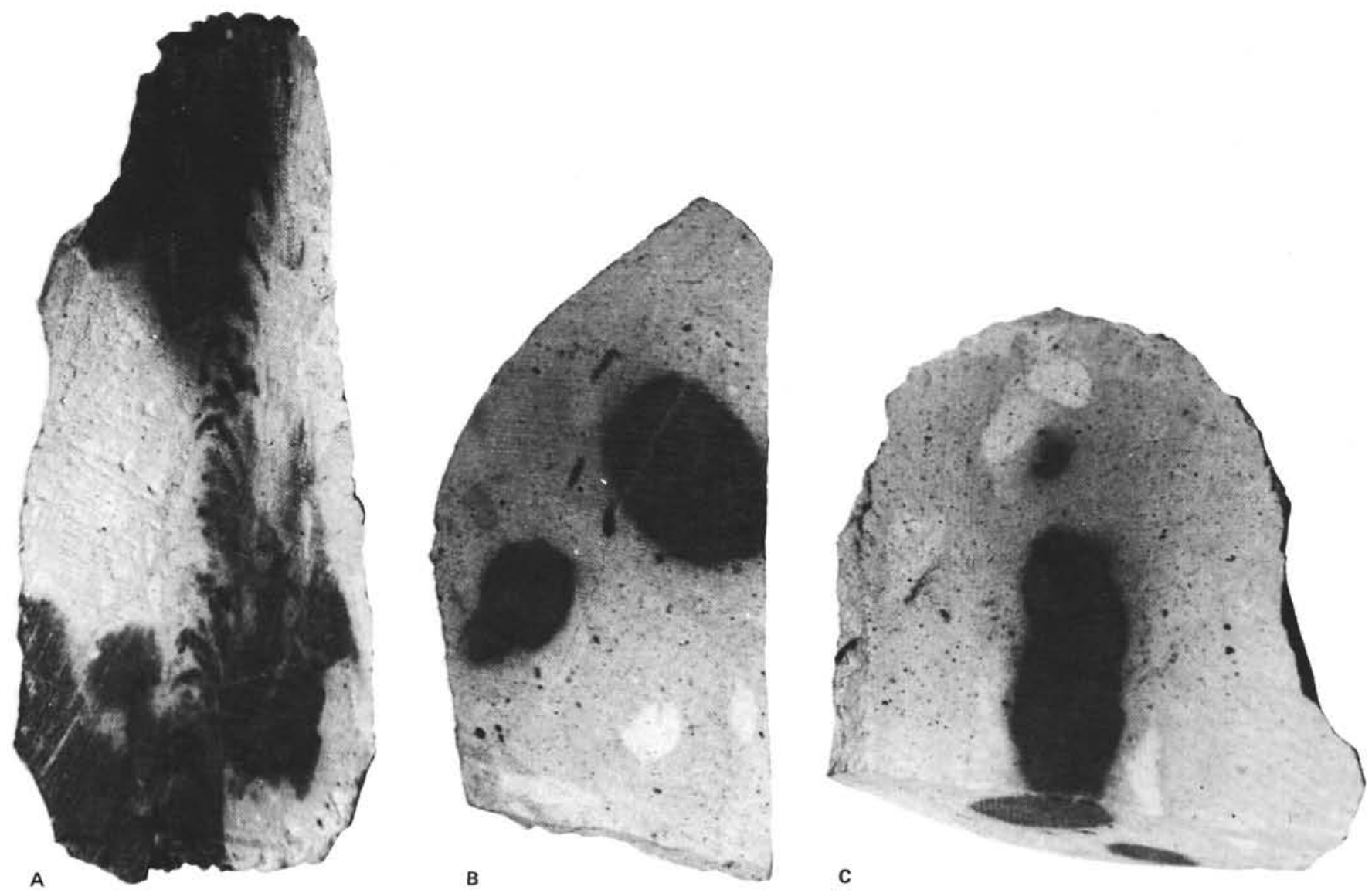

Figure 1. Cherts (black) in carbonate deposits (light). Magnifications are final magnifications. A, Sample 516F-17-1, 68-69 cm, magnification $2 \times$; B, Sample 516F-17,CC, magnification $1.3 \times$; C, Sample $516 \mathrm{~F}-4-6,128-131 \mathrm{~cm}$, magnification $1.3 \times$.

Table 1. Chemical composition of cherts and porcellanites from Hole $516 \mathrm{~F}$.

\begin{tabular}{lcrrrr}
\hline \multicolumn{5}{c}{$\begin{array}{c}\text { Core-section } \\
\text { (interval in cm) }\end{array}$} \\
& $4-6,128-131$ & $17-1,68-69$ & $17, \mathrm{CC}$ & $18-1,102-104$ & $80-1,90-91$ \\
\hline $\mathrm{SiO}_{2}$ & 74.20 & 76.30 & 75.50 & 66.85 & 60.00 \\
$\mathrm{TiO}_{2}$ & 0.04 & 0.06 & 0.06 & 0.04 & 0.02 \\
$\mathrm{Al}_{2} \mathrm{O}_{3}$ & 1.15 & 1.84 & 1.75 & 1.24 & 0.50 \\
$\mathrm{Fe}_{2} \mathrm{O}_{3}$ & 0.30 & 0.65 & 0.39 & 0.36 & 0.77 \\
$\mathrm{MnO}$ & 0.01 & 0.01 & 0.01 & 0.01 & 0.04 \\
$\mathrm{MgO}$ & 0.87 & 1.20 & & 1.00 & 1.50 \\
$\mathrm{CaO}$ & 9.00 & 6.36 & 7.18 & 13.05 & 16.00 \\
$\mathrm{Na}_{2} \mathrm{O}$ & 0.73 & 0.79 & 0.26 & 0.85 & 1.33 \\
$\mathrm{~K}_{2} \mathrm{O}$ & 0.20 & 0.27 & 0.26 & 0.19 & 0.05 \\
$\mathrm{Loss}$ of ignition & 13.50 & 13.50 & 14.90 & 16.60 & 20.90 \\
$\mathrm{Total}$ & 100.00 & 100.98 & 100.31 & 100.19 & 101.11 \\
$\mathrm{CO}_{2}$ & 7.07 & 5.00 & 5.64 & 10.25 & 12.57 \\
\hline
\end{tabular}

Note: Analyses of $\mathrm{CO}_{2}$ and loss of ignition were made by the weight method by N. P. Tolmacheva and T. G. Kuzmina. Other analyses were made by X-ray fluorescence by T. G. Kuzmina. A blank indicates that the sample was not investigated for that compound.

$\mathrm{CaCO}_{3}(11-29 \%), \mathrm{H}_{2} \mathrm{O}(6-9 \%)$, and some aluminosilicate admixture $(2-4 \%)$.

\section{SCANNING ELECTRON MICROSCOPE OBSERVATIONS}

Under scanning electron microscope, differences in the character of the contact between porous chalk and that of the dense "molten" chert are apparent. Skeletal remains of foraminifers and nannofossils point to the relict organogenic nature of cherts. Well-developed lepispheres of opal-CT occupy the chambers of planktonic foraminifers and intergrain spaces (Fig. 2), and the succession of authigenic mineral formation in porcellanite is calcite-opal-CT-dolomite. This succession is fully analogous to the vertical zonation of authigenic minerals (from the top downwards) in the carbonate section of Rio Grande Rise sediments. Sometimes well-formed crystals of zeolite (clinoptilolite?) can be found in porcellanite.

\section{X-RAY AND INFRARED ABSORPTION ANALYSES}

X-ray diffractograms (Fig. 3) and infrared absorption spectra (Fig. 4) show that opal-CT, quartz, calcite, and authigenic opal-CT are the principal minerals of cherts. Opal-CT, calcite, and, in minor quantities, dolomite and opal-A, but not quartz, were found in the porcellanite.

Variations of the calcite/opal-CT ratio on diffractograms and infrared spectra correspond to the variations recorded in the chemical analyses (Table 1). Aluminosilicate minerals are not reflected in this instance because of their negligible content.

The available materials allow us to consider opal-CT as the main form of authigenic $\mathrm{SiO}_{2}$ in the Hole $516 \mathrm{~F}$ 

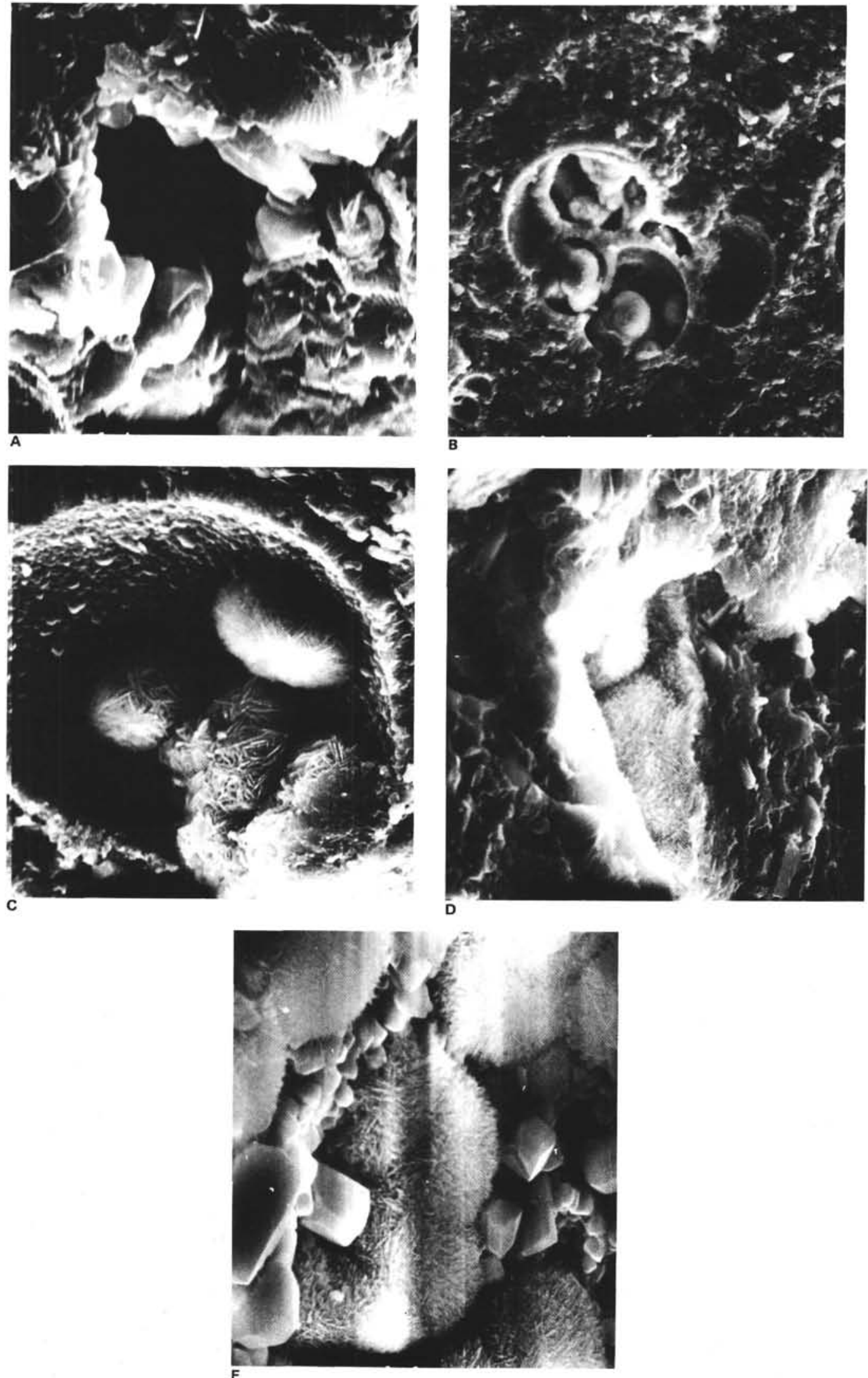

Figure 2. Cherts under scanning electron microscope. Magnifications are final magnifications. A, crystals of authigenic calcite and coccoliths in Sample 516F-4-6, 128-131 cm, magnification $4200 \times$; B, lepispheres of opal-CT in chambers of planktonic foraminifers; Sample $516 \mathrm{~F}-4-6,128-131 \mathrm{~cm}$, magnification $850 \times$; C, same as B, $2250 \times$; D, filling of intergrain space with joined lepispheres of opal-CT, Sample 516F-80-1, 90-91 $\mathrm{cm}$, magnification $1400 \times$; E, crystals of authigenic dolomite in the porcellanite, Sample $516 \mathrm{~F}-80-1,90-91 \mathrm{~cm}$, magnification $2800 \times$. 


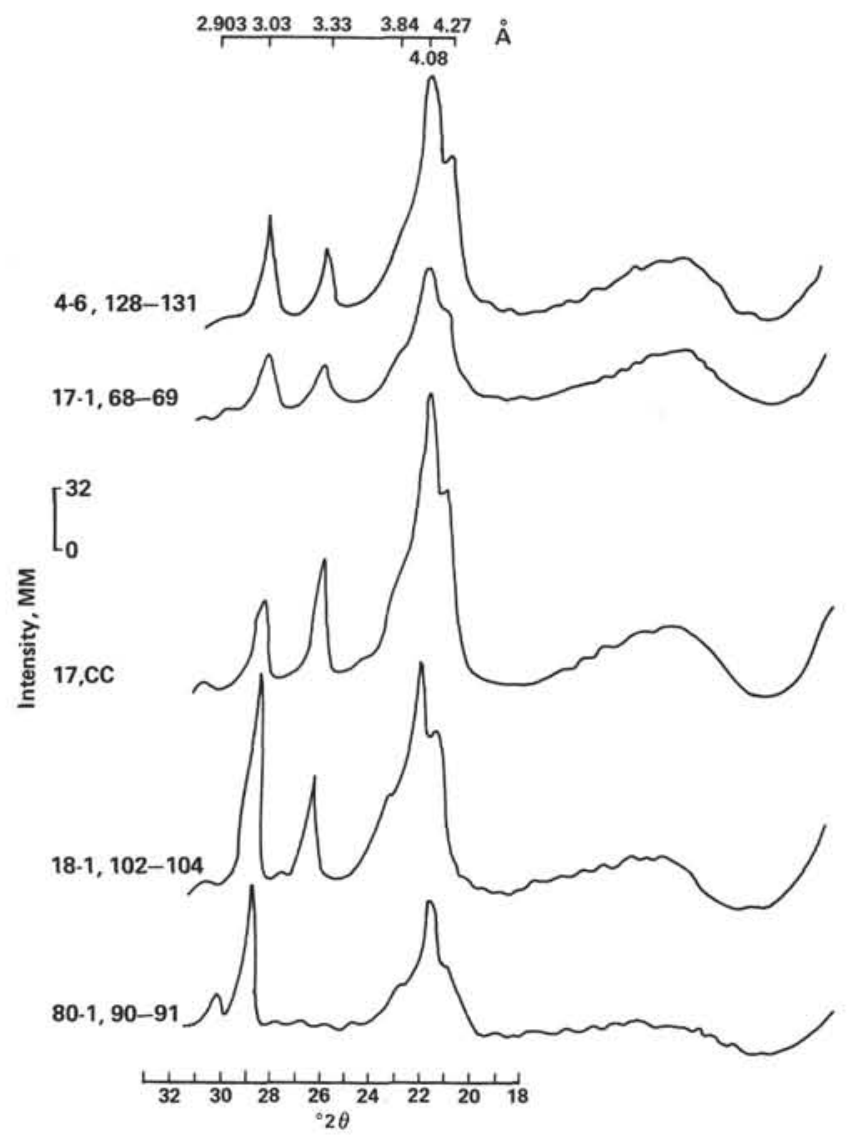

Figure 3. X-ray diffractograms of Hole $516 \mathrm{~F}$ cherts ( $\mathrm{CuK} \alpha$ radiation).

samples. Peak heights measured from the X-ray diffractograms (Fig. 3) reveal some trends in the relationships between the authigenic silica minerals (Table 2).

The cherts from upper Oligocene deposits within the sub-bottom range of $322-332 \mathrm{~m}$ have a strongly variable mineral composition. If, however, average values are taken, the decrease of opal-A and opal-A/opal-CT ratio with increasing age and sub-bottom depth can be considered well proven.

Much less certain is the trend of an increased ratio of quartz/opal-CT in the upper Oligocene cherts compared to the lower Miocene cherts. Many more samples are required for firmer conclusions about the mineralogy of $\mathrm{SiO}_{2}$. The cause of the absence of quartz in the oldest and most deeply buried sample of porcellanite remains unknown.

The isotopic composition of carbonates from cherts indicates that complete isotopic exchange between biogenic carbonates and interstitial waters took place (Ta-

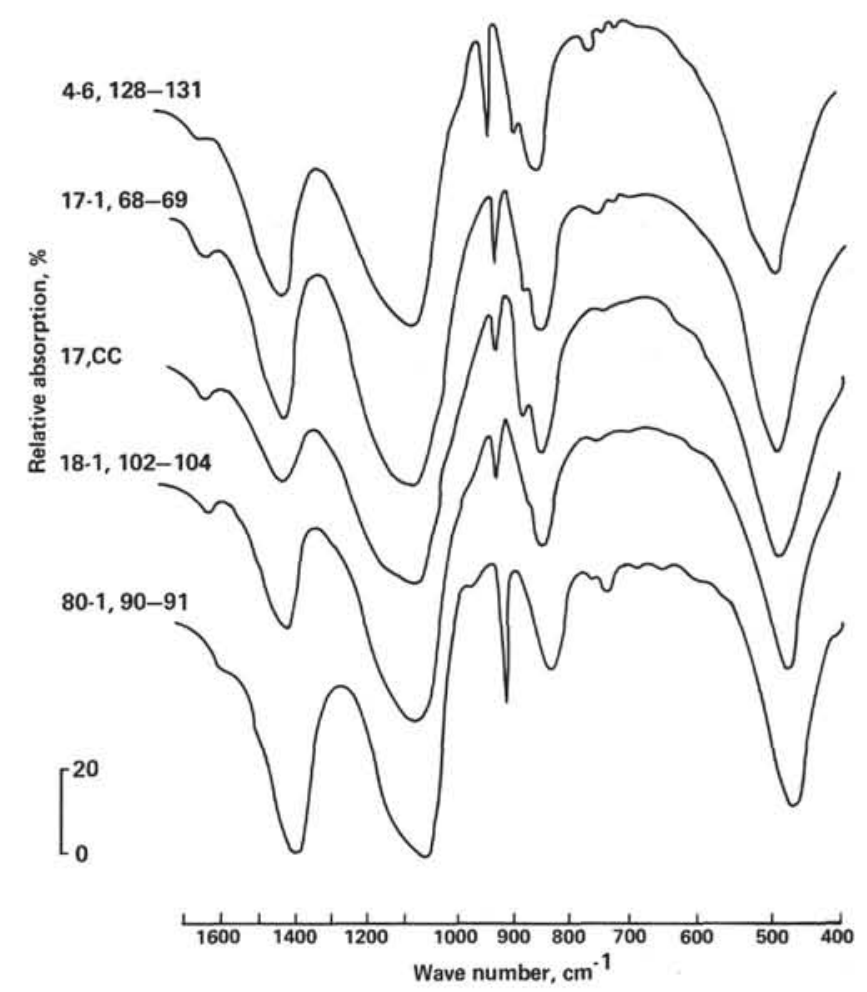

Figure 4. Infrared absorption spectra of Hole $516 \mathrm{~F}$ cherts.

ble 3). The diagenetic carbonates were deposited under conditions of isotopic equilibrium with interstitial water. Isotope indicators of biogenic carbonates have been obliterated in the course of postsedimentation processes.

\section{DISCUSSION}

At present most authors consider biogenic $\mathrm{SiO}_{2}$ as the main source for chert formation. We have already mentioned the occurrence, though rare, of radiolarian skeletal remains replaced with calcite and noted recrystallized sponge spicules both in the transitional zone around cherts and within them. Siliceous remains $(2-5 \%)$ occur in the lower Miocene of Hole 516F but were absent in older sediments.

Table 4 summarizes the data on the correlation of stratigraphic levels of enrichment with biogenic and authigenic $\mathrm{SiO}_{2}$ in the southwestern Atlantic sediment cover. As shown in Table 4, in the samples from Southwestern Atlantic one can readily see the downward displacement of both the upper and the lower boundaries of the age of sediments containing cherts compared to the age range of sediment enrichment with biogenic silica.

Table 2. Ratios of main peak heights of $\mathrm{SiO}_{2}$ minerals on diffractograms of cherts from Hole $516 \mathrm{~F}$.

\begin{tabular}{|c|c|c|c|c|c|c|c|c|}
\hline No. & $\begin{array}{l}\text { Core-section } \\
\text { (interval in } \mathrm{cm} \text { ) }\end{array}$ & Age & $\begin{array}{l}\text { Depth } \\
\text { (m) }\end{array}$ & $\begin{array}{c}\text { Opal-A (mm) } \\
\text { (halo 6-16 } \\
2 \theta)\end{array}$ & $\begin{array}{c}\text { Opal-CT (mm) } \\
(4.08- \\
4.11 \AA)\end{array}$ & $\begin{array}{c}\text { Quartz } \\
(\mathrm{mm}) \\
(3.33 \AA)\end{array}$ & $\begin{array}{c}\text { Ratio } \\
\text { opal-A/ } \\
\text { opal-CT }\end{array}$ & $\begin{array}{c}\text { Ratio } \\
\text { quartz/ } \\
\text { opal-CT }\end{array}$ \\
\hline 1 & $4-6,128-131$ & early Miocene & 206 & 30 & 113 & 31 & 0.27 & 0.27 \\
\hline 2 & $17-1,68-69$ & late Oligocene & 322 & 28 & 67 & 22 & 0.42 & 0.33 \\
\hline 3 & $17, \mathrm{CC}$ & late Oligocene & 324 & 33 & 411 & 59 & 0.08 & 0.14 \\
\hline 4 & $18-1,102-104$ & late Oligocene & 332 & 25 & 107 & 51 & 0.23 & 0.48 \\
\hline 5 & Average for \#'s 2, 3, 4 & late Oligocene & 326 & 29 & 195 & 44 & 0.24 & 0.32 \\
\hline 6 & $80-1,90-91$ & early-middle Eocene & 878 & 11 & 63 & 0 & 0.18 & 0 \\
\hline
\end{tabular}


Table 3. Isotopes of carbon and oxygen in chert carbonates from Hole $516 \mathrm{~F}$ samples.

\begin{tabular}{lcc}
\hline $\begin{array}{c}\text { Core-section } \\
\text { (interval in cm) }\end{array}$ & $\begin{array}{c}\delta^{13} \mathrm{C} \\
\% \text { PDB }\end{array}$ & $\begin{array}{c}\delta^{18} \mathrm{O} \\
\text { standard } \\
\text { mean ocean water }\end{array}$ \\
\hline $4-6,128-131$ & -1.1 & +34.6 \\
$17, \mathrm{CC}$ & -2.3 & +33.3 \\
$18-1,102-104$ & -3.2 & +34.5 \\
$80-1,90-91$ & -1.2 & +32.0 \\
\hline
\end{tabular}

Table 4. Stratigraphic levels of enrichment of the southwestern Atlantic sediment cover with $\mathrm{SiO}_{2}$ of different genesis.

\begin{tabular}{|c|c|c|c|}
\hline $\begin{array}{l}\text { Morphologic } \\
\text { feature }\end{array}$ & Hole & $\begin{array}{l}\text { Enrichment of sediments with } \\
\text { biogenic } \mathrm{SiO}_{2}\end{array}$ & $\begin{array}{l}\text { Authigenic } \mathrm{SiO}_{2} \\
\text { in sediments }\end{array}$ \\
\hline \multirow[t]{3}{*}{ Rio Grande Rise } & 22 & late Oligocene-early Miocene & middle Eocene, late $\mathrm{O}$ \\
\hline & 357 & & $\begin{array}{l}\text { Santonian, early Paleocene- } \\
\text { early Eocene }\end{array}$ \\
\hline & $516 \mathrm{~F}$ & Absen & $\begin{array}{l}\text { middle Eocene, late Oligo- } \\
\text { cene, early Miocene }\end{array}$ \\
\hline \multirow{2}{*}{ São Paulo Plateau } & 356 & ear & early Eocene \\
\hline & 355 & & No \\
\hline it & 515 & late Oligocene-middle Miocene & ? \\
\hline Argen & 358 & $\begin{array}{l}\text { late Oligocene-early Miocene; } \\
\text { late Miocene-Pleistocene }\end{array}$ & $\begin{array}{l}\text { middle Eocene-middle Oligo- } \\
\text { cene; middle Miocene }\end{array}$ \\
\hline Falkland Rise & 513 & late Oligocene-Pleistocene & early Oligocene \\
\hline
\end{tabular}

Note: ? indicates lack of information concerning $\mathrm{SiO}_{2}$ in that hole.
Similar analysis (with mapping) for the Pacific sediment cover (Levitan and Bogdanov, 1980) has shown that chert formation in Cenozoic deposits is restricted to areas with high absolute masses of biogenic silica. This trend was not established for Mesozoic deposits.

Finally, the comparison of evolution of the biogenic silica accumulation in the World Ocean (Levitan and Bogdanov, 1980) on one hand with the ratio frequency of cherts/age (Levitan, 1980) on the other, reveals an inverse trend and age displacement of biogenic and authigenic silica accumulations.

In conclusion, the local and regional features of biogenic and authigenic $\mathrm{SiO}_{2}$ ratios at Hole $516 \mathrm{~F}$ and in the southwestern Atlantic sediment cover reflect the general principles valid for the whole of the ocean.

\section{REFERENCES}

Calvert, S. E., 1971. Nature of silica phases in deep sea cherts of the North Atlantic. Nature Phys. Sci., 234(50):133-134.

Levitan, M. A., 1980. The silica as the object of diagenesis under ocean conditions. In Monin, A. S., and Lisitzin, A. P. (Eds.), The Geologic History of the World Ocean: Moscow (Nauka), pp. 351-358. (in Russian)

Levitan, M. A., and Bogdanov, Y. A., 1980. The evolution of the ocean silica accumulation and some aspects of chert formation. In Tkachuk, L. G. (Ed.), Sediment Rocks and Ores: Kiev (Naukova dumka), pp. 159-173. (in Russian)

Date of Initial Receipt: February 16, 1982 